\title{
IMPACT OF PLURILINGUALISM ON LEARNING QUALITY IN EVENING (SHIFT) SCHOOLS
}

\author{
Ineta Luka \\ Turiba University, Latvia \\ Tamara Pigozne \\ University of Latvia, Latvia \\ Svetlana Surikova \\ University of Latvia, Latvia
}

\begin{abstract}
This paper presents the main findings of the second stage of the Asia-Europe Meeting (ASEM) Lifelong Learning study (2011-2014) on identification of good practices that facilitate adult learning (aged 18-24) engagement in second chance education in evening (shift) schools. It analyses students' perceptions of plurilingual learning processes and the impact of people's plurilingualism on their learning. The methodology of early school leavers' learning in working life research was used applying combined phenomenological semi-structured and narrative interviews. 116 people (72 early school leavers and 44 second chance education teachers) representing all geographical regions of Latvia were addressed. The study identifies the differences between learning of bilingual and plurilingual people in formal and informal learning environments and describes the impact of plurilingualism on the learning quality.
\end{abstract}

Keywords: bilingualism, informal learning, learning, learning to learn, plurilingualism.

\section{Introduction}

Globalization, rapid development of new information and communication technologies, ongoing increase in knowledge production speed requires the development of new competencies. Understanding and speaking many languages is essential.

Plurilingualism has become a widespread social reality and it is a part of many people's lives nowadays. It can be even said that plurilingualism is an everyday experience (Bach \& Wolff, 2013).

In Latvia, people traditionally learn more than two languages, which is caused by the special status of small countries where in order to survive it is necessary to learn other languages. According to Eurobarometer survey in 2006, $56 \%$ of respondents indicated they were able to speak at least one foreign language. The countries with the highest rates of multilingualism were: Luxembourg, with $99 \%$ saying they spoke at least one foreign language; Slovakia (97\%) and Latvia (95\%). The Eurobarometer survey in 2012 showed that almost all respondents in Luxembourg (98\%), Latvia (95\%), the Netherlands (94\%), Malta (93\%), Slovenia (92\%), Lithuania (92\%), Sweden 
(91\%) admitted being able to speak at least one language in addition to their mother tongue (Europeans and their languages, 2012).

The fact that most people in Latvia speak several languages urged the authors of the paper to study if there are differences between learning of bilingual and plurilingual people in formal and informal learning environments, and which impact plurilingualism could have on the learning quality. In this paper the authors are seeking the answers to the question - what exactly is required in order to be able to face challenges of the future. Answers to this question have been sought both by analyzing previous studies and surveying young adults (aged 18-24) engaged in second chance education in evening (shift) schools of Latvia since in Europe special attention has recently been paid to young adults as one of the target groups of lifelong learning.

In order to attain the EU benchmarks for 2020 (ET 2020, 2009; Europe $2020,2010)$ regarding participation of young adults in lifelong learning and increasing their competence level and upgrading knowledge, the primary focus has been on early school leavers. The key issue is the evaluation of the existing educational offer for the target group in order to find out the possibilities of improving the current education practice.

This problem has been in the focus of attention since 2010 when the share of early school leavers (aged 18-24 years) in Latvia constituted $13.3 \%$ of the target population. Although there is a trend for the number of early school leavers to decrease - in 2011 the number decreased to $11.6 \%$ and in 2012 to 10.5\% (Early Leavers from Education and Training Aged 18-24, 2013), the problem still exists and new, contemporary, effective ways for learning are being investigated.

One of the opportunities how to obtain formal education is evening (shift) schools that have long traditions in Latvia and that offer both general secondary education and vocationally oriented secondary education. Evening (shift) schools offer to acquire education in evening groups, extramural groups, for people in custody and even e-learning. They are open to everyone who has such a need and as argued by Karnite (2012) their success factor is their flexibility.

Teachers of evening schools have adapted to work with students having different levels of knowledge, skills and competences, different motivation, age and social status. An advantage of evening (shift) schools is teachers' tolerance, understanding of their students and readiness to change.

It has to be emphasized that the majority of evening (shift) schools are the second chance education institutions in Latvia. The programs for such schools are developed according to the demand (Country Report on the Action Plan on Adult Learning: Latvia, 2011).

The current research started in 2011 when a trend in closing down evening (shift) schools in the country was evident. In 2008/2009 there were 34 evening schools $(13,223$ learners) in the country. Their number decreased to $28(12,732$ learners) in 2010/2011 and further on to 25 (12,002 learners) in 2011/2012. In 
the study year 2012/2013 the number of evening (shift) schools remained the same ( 25 schools) but the number of students decreased to 11,727 , which may also be explained by the demographic situation in the country (Statistika par vispārējo izglìtību, 2009; 2011; 2012). The evening (shift) schools have been located throughout the country, mainly concentrating in the largest cities.

However, despite the created network of evening (shift) schools and their long traditions in Latvia, the practice showed that the activity of the existing educational institutions did not adequately promote adult participation in learning. Considering the above-analyzed context, the authors researched the impact of plurilingualism on the learning processes.

\section{Theoretical Framework}

The study is based on the analysis of theoretical and empirical studies on plurilingualism and learning.

The concept of plurilingualism has been developing for more than thirty years. Different approaches have dominated in different periods of time. For example, in 1970ies Wandruszka (1979) considered that plurilingualism was innate in all individuals and he called it internal plurilingualism. The author implies that even in mother tongue speakers switch over from one language style to another, one dialect to another, and so on. He also introduced the term external plurilingualism addressing it to an individual's ability to learn other languages in addition to their mother tongue. According to Neuner (2004), for more than twenty years plurilingualism was associated with natural language acquisition processes in which speakers have developed a similar competence level in all languages. The latest concept of plurilingualism postulates that languages contribute to each other and it is not necessary to attain native-like language competence in all languages (Neuner, 2004).

In the present paper the authors have adopted the approach that plurilingual is a person using two or more languages in their daily lives. Plurilingualism is perceived as one competence which encompasses a range of languages in a variety of contexts (Valuing All Languages in Europe, 2011). Thus, languages are becoming a tool for learning other subjects, and many languages give certain advantages for an individual to learn.

\section{Plurilingualism - a "way of life in Europe"}

Eurobarometer survey points to 23 officially recognized languages and more than 60 indigenous regional and minority languages, and many nonindigenous languages spoken in Europe. 88\% of Europeans consider that languages other than their mother tongue are useful for personal development (Europeans and their languages, 2012) which clearly indicates to plurilingualism in Europe. 
In general, plurilingualism is associated with the person's "ability to use languages for the purposes of communication and to take part in intercultural interaction, where a person, viewed as a social agent has proficiency, of varying degrees, in several languages" (CEFR, 2001: 168). Plurilingualism, the same as pluriculturalism, is regarded as a personal feature which is put into action in a communicative situation (Bernaus et al., 2007). Moreover, being plurilingual also describes a personal attitude. It comprises communication abilities as well as the awareness of the world as multilingual and the ability to live in multilingual contexts (Bach \& Wolff, 2013).

As previously said, everyday life for many people in the world is multilingual. However, plurilingual people are often still considered as extraordinary people. Unfortunately, this understanding often leads to the pointof-view that such people do not master any of the languages. Therefore, a special role of the present paper is to show that these people can speak these languages, can apply them in problem solving situations and attaining their personal aims. Understanding and speaking of many languages is one of the dimensions in future competencies; plurilingualism has even been claimed to be a "way of life in Europe" (Beacco, 2005). Plurilinguals are people who claim to possess a plural linguistic and cultural repertoire, developed through a variety of experiences which promotes the development of different competencies at various levels (Beacco, 2005). The focus here is not on the simple addition of various languages, but on the learning processes which occur when people learn new languages and learn in general. Learners may be or become plurilingual individuals (Bach \& Wolff, 2013). Among other benefits of plurilingualism the following ones have to be stressed: 1) heightened capacity to compete in the knowledge economy, 2) greater opportunities for participation in public life, and for shaping democratic practices, 3) better strategies to combat prejudice, promote tolerance and mutual understanding (Valuing All Languages in Europe, 2011).

Certainly, languages open the door to people who want to succeed in the modern globalized society. "There is empirical evidence that skill in several languages fosters creativity and innovation: multilingual people are aware that problems can be tackled in different ways according to different linguistic and cultural backgrounds and can use this ability to find new solutions" (Multilingualism: an asset for Europe and a shared commitment, 2008: 8). And, problem-solving, flexibility, creativity, innovation and learning-to-learn are essential attributes to succeed in the versatile and rapidly developing world.

\section{Learning-to-learn through languages - a necessary competence for the future}

Nowadays, learners in most regions of Europe bring many different languages to school with them. This means that plurilingualism is an important component of education for all learners. It is not connected with only language 
learning, but it also impacts all learning and helps developing learners' cooperation strategies (Boeckmann et al., 2011).

The studies (Boeckmann et al., 2011; Neuner, 2004; Krumm, 2004) reveal the significance of languages in learning other subjects. "The language of the subject represents the knowledge structure of that subject and is one of the central tools for studying it. Language competence is thus an integral part of subject competence, and the two can hardly be separated from each other" (Boeckmann et al., 2011: 11), i.e., "learning a new subject largely consists of learning a new language. This is why learners of language(s) in other subjects can draw on their experience and competences from language(s) as a subject that they have acquired beforehand or are acquiring simultaneously" (ibid: 11-12). This means that the learning strategies developed in language learning are applied when acquiring other subjects.

Learning through languages - promoting inclusive, plurilingual and intercultural education is the goal of the European Centre for Modern Languages programme for 2012-2015 and languages represent the principal medium through which learning is achieved (Learning through languages, 2013). In turn, plurilingualism is not achieved by overlapping or juxtaposing different competences, as it is a global and complex competence which has four main dimensions: 1) the socio-affective dimension, 2) the dimension of linguistic and communicative registers, 3) the dimension of learning strategies, and 4) the dimension of interaction management. These dimensions comprise the learner's ability to maintain a dialogue, use their previous experience and knowledge in other situations, be ready to resolve communication problems and manage communication in situations characterized by linguistic and cultural plurality (Bernaus et al., 2007). Language learning stimulates learner's openness to new learning experiences and helps attaining relevant competences in other courses. Language is a tool for acquiring and transferring knowledge.

\section{Methodological Framework}

The present research is the second stage of the Asia-Europe Meeting (ASEM) Lifelong Learning study "Identification and analysis of new challenges and solutions that have influence on engagement and reintegration of adults (1824 years) in lifelong learning" (2011-2014) and it identifies good practices that will facilitate adult learning engagement in second chance education in evening (shift) schools. The study was managed by the State Education Development Agency of Latvia in collaboration with the University of Latvia (ESF Project Support to Education Research, Activity 1.2.2.3.2.). Its goal was to work out evidence based recommendations for the Ministry of Education and Science of Latvia for curricula development for 2013-2020 in Asian and European perspective in order to increase the ratio of inhabitants (aged 18-24) with basic and secondary education engagement in learning. The results of the study reveal 
what changes have to be introduced in order to more effectively engage adults in learning by using the existing infrastructure, analysing obstacles (challenges) and good practice of how to eliminate obstacles (demonstrate good practice of opportunities) in engaging adults with incomplete basic or secondary education in the learning process. The present paper deals with the analysis of the findings from the qualitative part of the study - focus group discussions with learners and teachers (2012-2013).

In this paper the authors deal with individuals' perceptions of plurilingual learning processes and the impact of people's plurilingualism on their learning (research question). The authors propose to: 1) identify the differences between learning of bilingual and plurilingual people in formal and informal learning environments; 2) analyze how cognitive, affective and social dimensions interplay in plurilingual people's learning; 3) describe the impact of plurilingualism on the earning quality. The authors are convinced that the good practice of the impact of plurilingualism upon the learning quality may be interesting in European and world wide learning quality perspective.

The methodology of studying of early school leavers' learning in working life was used (Illeris, 2004; 2005) applying a combined phenomenological semistructured and narrative interviews (Kvale, 1996). Learning histories were collected in focus group discussions as audio files, then coded in a 5 researchers' group applying the coding system developed in the study on the relationships between characteristics of workplace practices and types of informal learning (Doornbos et al., 2008) and analysed applying AQUAD 6 software (Huber \& Gürtler, 2003). Implicit theories of the interplay of cognitive, affective and social dimensions in plurilingual people's learning were explored, expressions were analyzed, as well as linkages among the categories and implicants were determined and analyzed. The findings were statistically validated by applying the latest AQUAD software and SPSS software.

116 people representing all five geographical regions of Latvia (Riga, Kurzeme, Vidzeme, Latgale, Zemgale) were reached. 72 of them were early school leavers (male $=25$; female $=47$ ) and 44 were second chance education teachers $($ male $=3$; female $=41$ ) which corresponds to the actual feminized situation of teachers in the schools of Latvia.

\section{Findings and Discussion}

The findings connected with learning and languages showed that most students were plurilinguals, whereas the teachers were bilinguals. The codes of frequencies regarding the use of different languages were more expressed in students' discussions (202 codes) compared to teachers' discussions (135 codes). Informants admitted that they had learnt languages in formal education (83 frequencies) and in non-formal education (27 frequencies), as well as in informal situations at work and life. Regarding informal learning, the informants 
acknowledged learning languages at life more than at work (89 frequencies vs. 32). Several informants, especially students, admitted that they had lived and worked abroad. The informants also expressed their ideas on the learning process and the learning outcomes.

The results of Chi Square Test confirm a significant difference $(p \leq 0.01$; $\left.\chi^{2}=64.98\right)$ between the students' and the teachers' answers. Students predominantly are assessment-oriented and content-oriented. Both, students and teachers are process-oriented.

Students stress the role of individual learning in language learning process, whereas teachers emphasize learning from colleagues:

I am not quite experienced. I have been learning from my colleagues a lot. At the same time, I am teaching them as well. I have understood that I can learn from communication and experience which are constantly updating. The more I communicate, the more ideas I have.

Both, students and teachers admit learning together and learning from experts, i.e., experienced people:

Last summer I went to England and worked in an on-line shop. I liked that every morning started with a joint meeting - evaluation of the day, suggestions how to improve work. I was told what was good and what needs to be improved, they also taught me. It's very important.

However, learning outside the accustomed learning environment is characteristic only to students. Nearly all students and half of teachers learn languages in formal and informal (everyday) learning process. A part of students and a part of teachers admit workplace learning and prefer non-formal ways of learning.

Students feel that they have learnt something when they have good knowledge and skills. The following quotations illustrate this:

When I am aware of what is going on, when I understand everything, when I know taht I can do it and I do not need anyone's help.

Learning is a process of self-assurance and elimination of fear; when I see the result, I am satisfied.

When I can do it, I am glad. When I can speak to a foreigner and see that he has understood me, I can do it. I could't earlier, but now I can.

Teachers consider that they have learnt something when they have attained a definite competence level, and when they are able to creatively apply the acquired knowledge and skills in different situations. For example:

When I can freely speak about the topic, express everything what I think and tell it to others.

It is essential for me to be self-assured, calm at a certain situation andbe able to communicate with others. Learning is like a flowing river. There are some things that we learn during the course of life, which are really useful in 
communication. But there are very many things that are changing, and we have to accept it. We have to change ourselves.

If I can overcome some barriers in me which I could not do earlier; when I do something new which I could have never thought of before. Then I consider that I have learnt something. This is my step ahead.

Both, teachers and students emphasize that in everyday life they face situations which they have not encountered before and when solving the problems they gain positive experience:

I think 'lifelong learning' is exactly for me. I learn everywhere, at any situation, at any time, from all the people I have ever met, and not only.

Experience exchange, when students organize meetings, express their point-of-view, what could be improved, what they like and what not. Students and teachers learn together, in a group. They think about others, not only about themselves. They discuss what each has found, understood, can suggest others. Learning together is cooperation.

Learning is formulation of one's own opinion, developing oneself. The more one knows, the more developed individuality one is.

Sometimes they point to negative experience, although this negative experience is more characteristic to teachers than students.

In order to verify if the findings obtained may be generalized and referred to other contexts as well, Mann-Whitney $U$ test for two independent samples as well as Crosstabulation for determining $\chi^{2}$ was applied. The results showed that in the language learning process students compared to teachers are more assessment-oriented $\left(\mathrm{p}=0,016 ; \chi^{2}=0,015\right)$. Students prefer individual learning $\left(\mathrm{p}=0,001 ; \chi^{2}=0,001\right)$, informal learning at life $\left(\mathrm{p}=0,000 ; \chi^{2}=0,000\right)$, formal language learning $\left(\mathrm{p}=0,000 ; \chi^{2}=0,000\right)$, knowledge acquisition $(\mathrm{p}=0,014$; $\left.\chi^{2}=0,014\right)$ and they are more plurilingual than teachers $\left(\mathrm{p}=0,017 ; \chi^{2}=0,017\right)$. In turn, teachers are more oriented to learning from colleagues $\left(\mathrm{p}=0,017 ; \chi^{2}=0,017\right)$ and to the competence development $\left(\mathrm{p}=0,017 ; \chi^{2}=0,017\right)$.

The linkages constructed with a 3 minute intervals in order to find out the relationships between different phenomena, pointed to five types of linkages: 1) between plurilingualism and non-formal learning; 2) between plurilingualism and informal learning at life; 3) between plurilingualism and formal learning; 4) between plurilingualism and informal learning at work; 5) between bilingualism and informal learning at life.

The linkage (relationship) between plurilingualism and non-formal learning was discovered in 27 cases. It was especially exposed in the focus group discussion in Riga region were 11 confirmations of this relationship were discovered. More confirmations were also found in the focus group discussions in Latgale region, which historically has been the region where two, even three, languages (Latvian and Russian) had coexisted, and a special dialect of the 
Latvian language - the Latgalian has been spoken in that region as well. The following quotations are some examples of the above-said:

I learnt German at school. Then I decided to learn English. I attended the course organized by the Employment Agency and I admit that I have learnt something. To be sure that I can speak a language, I checked it during my trip. I felt that it had been worth learning.

I learn at Students' Council a lot. There are projects at school and I can learn there. Last year we had a project which gave us a possibility to go to France and work one day in Euro Parliament. I learnt a lot there!

The linkage between plurilingualism and informal learning at life was discovered in 68 cases. The relationship was found both in students' and in teachers' focus group discussions. The construction of linkages had more confirmations than the ones to confirm the relationship between plurilingualism and non-formal learning, which points to closer relationship between informal language learning at life and language application in practice than non-formal language learning of plurilinguals. Confirmations were discovered in Riga, Latgale and Kurzeme regions. This also points to the fact that plurilinguals learn languages easier, not so much effort is devoted to extra hours of learning as they learn languages at life in their accustomed everyday environment. Thus, learning by doing is significant here: "I learn in practice. Learning is a process, a practical process" and "It is easier to learn something in action". Informants also stressed the role of environment in learning, for example:

It is easier to learn a language abroad, not communicating with people from one's motherland. I know people who have lived here for two years and could not learn the language. It is easier to learn communicating with others. If one goes abroad alone and communicates with foreigners only, one can learn the language in 2-3 months.

One can learn communicating to each other, listening to each other. If opinions differ, one can learn more. The more versatile opinions are, the more you find out, the more you learn.

I spent a week with a person who cannot speak Russian and Latvian. I could not speak English, so I did not know what to do. Then it came to my mind that it is possible to use drawings and thus solve the situation. When I wanted to eat, I drew some food and he told me the word in English - food, and thus I learnt this word. Next time I used the English word. I was trying to remember my childhood.

The linkage between plurilingualism and formal learning was discovered in 81 cases. The confirmations of the linkage were significant. It has to be emphasized that in two focus group discussions 17 confirmations of the present linkage were discovered which points to strong links between plurilingualism 
and formal learning. These links were especially expressed in students' focus group discussions, which was also natural as all students had studied Latvian and at least 2 foreign languages (mostly Russian and English) at school. Regarding their language competence level, most of them admitted being fluent in at least two languages and partially fluent or fluent in the third language.

The linkage between plurilingualism and informal learning at work was discovered in 21 cases. These confirmations were less vivid compared to the previously-mentioned confirmations of other relationship. However, it has to be added that all teachers were experienced and most of the students had at least some kind of work experience, too. Apparently, respondents had considered having learnt language at formal and non-formal education first and then applying the language skills at practice at work. Informants recognized having improved language skills during their work experience abroad, especially the English language skills.

The linkage between bilingualism and informal learning at life was the least expressed of all. It was discovered in 12 cases only. The confirmations ranged from 2 to 5, no distinct confirmations were found. However, these confirmations have to be taken into consideration as well, as the lines were analyzed with a 3 minute interval which allowed tracing the slightest nuances in respondents' answers.

In general, findings revealed relationships between plurilingualism and informal learning. Both, students and teachers consider that in everyday life they learn anything, including languages, mostly in spontaneous, previously not planned activities. Students and teachers learn the language in language environment, including e-environment by communicating face-to-face and online, electronically, when reading books, listening to music and watching movies. Teachers learn during their subject classes applying and explaining international terms, together with students communicating with collaboration partners as well as with youngsters, searching for all possible answers to students' questions, working in projects (welcoming project partners, presenting), in service industry (shopping, at the manicurist), travelling and during their business trips. Students learn by contacting with their friends, playing games, watching cartoons. Students who have work experience learn from "practical things that have to be done", their motivation is "to understand in detail what everything means in order to perform the work well".

Analysing teachers' expressions relationships were discovered between plurilingualism and non-formal learning. They learn languages with a private tutor, participating in specially arranged courses, raising their qualification abroad.

Analysing students' expressions relationships were discovered between plurilingualism and formal learning. They learn languages in educational institutions (at kindergarten and school) which are the main stages of hierarchically and chronologically structured education system of Latvia. They 
learn languages by studying vocabulary, memorizing the names for the objects, etc.

Next, implicants in interplay of cognitive, affective and social dimensions in learning of bilingual and plurilingual early school leavers (aged 18-24) and second chance education teachers in formal and informal learning settings were studied. The most significant findings of implicants are summarized below:

- Analysing informants' answers (students' and teachers' answers) the following most repeated set of conditions for bilingualism was discovered: the development of bilingualism was influenced only by a multilingual environment (4 cases);

- Analysing students' answers the most repeated set of conditions for bilingualism was discovered: the development of bilingualism was influenced only by a multilingual environment (4 cases);

- Analysing informants' answers (students' and teachers' answers) the following most repeated set of conditions for plurilingualism was discovered: plurilingualism was promoted by gaining positive experience in solving new situations (6 cases);

- Analysing students' answers the most repeated set of conditions for plurilingualism was discovered: plurilingualism was influenced only by the environment in which at least two languages are spoken (4 cases);

- Analysing teachers' answers the most repeated set of conditions for plurilingualism was discovered: plurilingualism was influenced by the link between language learning and the enhancement of attitude and competences ( 3 cases).

The research findings confirm the viewpoints that languages open the door to more opportunities in life; the more languages people speak, the more opportunities they have. Learning through languages has become a way of life.

According to the findings, the majority of the youngsters have gained experience abroad. It is even possible to say that in their situation the following order exists: language skills provide them an opportunity to get employment abroad, the employment abroad widens their experience, returning home students' choice to study in the evening (shift) school is very conscious and purposeful and it stems from their life and learning experience as well as corresponds to their aims. This is an example for learning through languages.

People are inspired to learn not only by their interest in languages and culture - instrumental or integrative motivation understood in the tradition of Gardner and Lambert (1972), but they also have other aims of life in which language is a tool or as cited above "Languages open the door".

It is evident that there are other factors that help the informants to solve complex tasks and provide that these processes happen naturally and no one finds them as a burden. They have aims of life and focussed interests. According to the notions by Illeris (2007) this interest and purposefulness provide the 
necessary interaction between cognitive and affective dimensions. This interaction with social processes secures successful learning.

It is evident that the learning process comes from the students themselves. All students are very motivated as they have chosen to return to the education system. Learning-to-learn competence is developing in process. They know how to learn which is expressed in their wish to study in the evening (shift) school as well as in the reason for their learning, which is confirmed by their expressions:

- Learning means to know how to use opportunities;

- Learning is to know how to solve the problem in the changing situation;

- I have learnt if I can solve a new situation;

- If I can independently do a task, it means that I have learnt;

- I have learnt when I can tell others what I have learnt about.

Experience gained from several socio-cultural contexts proved to be beneficial which also emphasizes the impact of plurilingualism on the learning processes.

\section{Conclusion}

The findings revealed the fact that plurilinguals and bilinguals perceive the learning process and learning outcomes differently.

For plurilinguals learning means implicate solution of critical situations by using different resources, problem-solving process, life activity as a result of which they overcome obstacles and develop self-assurance and build their career. It is a conscious life activity, communication, self-realization, situation analysis. Learning outcomes is a synergy as a result of which new ideas are created and which motivates setting up new targets, adequate self-assessment, and selection of optimal learning strategies.

Bilinguals associate learning with knowledge acquisition (I know how to do it), memorizing (learning lexis), comprehension on further knowledge application. Learning outcomes are associated with assessment (I know during the test, after it - not, examination).

Bilingualism interplays with cognitive and affective dimension of contentoriented learning in formal learning settings: learning is a difficult cognitive process (examples of expressions: agitate, excite, tense, and worry) the benefits of which are affective sense (be or feel at ease, breathe easy, interrupt work, take a break, take a breath). Whereas plurilingual ones - with social dimension of learning towards language use (speak fluently on the topic, help others, teach others, explain, tell about their experience) and they benefit from informal learning - use learning opportunities in any context, unintentional learning promotes independence, well-being, flexibility, knowledge transfer in new unknown situations, as well as transcultural communication. 


\section{SOCIETY. INTEGRATION. EDUCATION. Volume IV}

Cognitive and affective dimensions are connected with formal learning (lessons), and social dimension is connected with informal learning processes (to see the opportunities where it is possible to learn unintentionally).

\section{Acknowledgements}

The authors of the paper want to express their gratitude to Elina Maslo (Aarhus University, Denmark) for assistance in the research while working at the paper.

\section{References}

Bach, G., \& Wolff, D. (2013). Multi- and plurilingualism in teaching and learning (MSU). In S. Beidbach \& B. Viebrock (Eds.), Content and Language Integrated Learning (CLIL) in Europe (p. 6). Frankfurt am Main: Peter Lang Edition.

Beacco, J. C. (2005) Languages and language repertoires: plurilingualism as a way of life in Europe. Reference study. Strasbourg, Council of Europe.

Bernaus, M., Andrade, A.I., Kervran, M., Murkowska, A., \& Sáez, F.T. (2007). Plurilingual and pluricultural awareness in language teacher education. Graz: Europena Centre for Modern Languages, Council of Europe Publishing.

Boeckmann, K.B., Aalto, E., Abel, A., Atanososka, A., \& Lamb, T. (2011). Promoting plurilingualism. Majority language in multilingual settings. Graz: European Centre for Modern Languages, Council of Europe.

CEFR. (2001). Common European framework of reference for languages: Learning, teaching, assessment. Strasbourg: Council of Europe. Retrieved from: http://www.coe.int/t/dg4/linguistic/Source/Framework_EN.pdf [08.02.2015.]

Country Report on the Action Plan on Adult Learning: Latvia. (2011). GHK, Research voor Beleid, March 2011. Retrieved from: http://adultlearning-budapest2011.teamwork.fr/ docs/Country-report_LV_final.pdf [12.02.2015].

Doornbos, A.J., Simons, R.J., \& Denessen, E. (2008). Relations between characteristics of workplace practices and types of informal work-related learning: A survey study among Dutch Police. Human Resource Development Quarterly, 19(2), 129-151. doi: 10.1002/hrdq.1231

Early Leavers From Education and Training Aged 18-24. (2013). NBG37. Early leavers from education and training aged 18-24 in urban and rural areas by sex (\%). Retrieved from: http://data.csb.gov.lv/pxweb/en/Sociala/Sociala ikgad nodarb/NB0370.px/? rxid=562c2205-ba57-4130-b63a-6991f49ab6fe [04.07.2013.]

ET 2020. (2009). Council conclusions of 12 May 2009 on a strategic framework for European cooperation in education and training ('ET 2020') (2009/C 119/02). Retrieved from: http://eur-lex.europa.eu/legal-

content/EN/TXT/PDF/?uri=CELEX:52009XG0528(01)\&from=EN [07.02.2015.]

Europeans and their languages. (2012). Special Eurobarometer 386. Report. European Commission. Retrieved from: http://ec.europa.eu/public_opinion/archives/ebs/ ebs_386_en.pdf [07.02.2015.]

Europe 2020. (2010). A strategy for smart, sustainable and inclusive growth. Communication from the Commission. Brussels, 3.3.2010, COM(2010) 2020 final. Retrieved from: http://eur-lex.europa.eu/LexUriServ/LexUriServ.do?uri=COM:2010:2020:FIN:EN:PDF [07.02.2015.]

Gardner, R. C., \& Lambert, W.E. (1972). Attitudes and Motivation and Second-Language Learning. Newbury: Newbury House. 
Huber, G.L. \& Gürtler, L. (2003). Manual zur Software AQUAD 6 (Erstveröffentlichung). Tübingen: Ingeborg Huber Verlag.

Illeris, K. (2004). Learning in working life. Copenhagen: Roskilde University Press.

Illeris, K. (2005). Low-skilled workers learn at the workplace. Lifelong Learning in Europe, $10(3), 172-177$.

Illeris, K. (Ed.) (2007). Loeringsteorier. Seks aktuelle forståelser. Frederiksberg: Roskilde Universitetsforlag.

Karnite, R. (2012). Latvia: ERM comparative analytical report on Recent Policy Developments related to those Not in Employment, Education and Training (NEET). 7 February, 2012. Retrieved from: http://www.eurofound.europa.eu/emcc/erm/studies/ tn1109042s/lv1109049q.htm [07.04.2012].

Krumm, H.J. (2004). Language policies and plurilingualism. In B. Huffeisen \& G. Neuner (Eds.), The Plurilingualism Project: Tertiary Language Learning - German after English (pp. 35-50). Graz: European Centre for Modern Languages, Council of Europe Publishing.

Kvale, S. (1996). Interviews: An Introduction to Qualitative Research Interviewing. Thousand Oaks, CA: SAGE.

Learning through languages. (2013). Programme 2012-2015 of European Centre for Modern Languages. Retrieved from: http://www.ecml.at/ECML-Programme/Programme20122015/tabid/685/language/en-GB/Default.aspx [08.02.2015.]

Multilingualism: an asset for Europe and a shared commitment. (2008). Communication from the Commission to the European Parliament, the Council, the European Economic and Social Committee and the Committee of the Regions. Brussels, 18.09.2008, COM(2008) 566 final. Retrieved from: http://cordis.europa.eu/fp7/ict/language-technologies/ docs/multilingual-comm.pdf [07.02.2015.]

Neuner, G. (2004). The concept of plurilingualism and tertiary langauge didactics. In B. Huffeisen, G. Neuner (Eds.), The Plurilingualism Project: Tertiary Language Learning - German after English (pp. 13-34). Graz: European Centre for Modern Langauges, Council of Europe Publishing.

Statistika par vispārējo izglītību. (2009; 2011; 2012). Latvijas Republikas Izglītības un Zinātnes Ministrijas oficiālā mājas lapa. Retrieved from: http://izm.izm.gov.lv/registristatistika/statistika-vispareja.html [04.07.2013.]

Valuing All Languages in Europe. (2011). ECML Research and Development Reports Series. Graz: European Centre for Modern Languages.

Wandruszka, M. (1979). Die Mehrsprachigkeit des Menschen. Stuttgart: Kohlhammer. 